\title{
The Effects of Reciprocal Teaching Learning Strategy and Self efficacy on Learning Outcomes of Early Childhood (AUD) Mathematical Logic
}

\author{
Erwanto $^{1}$, Anastasia Sri Maryatmi ${ }^{2}$, Agung Budiyanto ${ }^{3}$ \\ ${ }_{1,2,3}$ Universitas Persada Indonesia Y.A.I, Jakarta \\ ${ }^{1}$ Correspondence Address; Erwan23@gmail.com
}

\begin{abstract}
The purpose of this research is to learn about the influence of Reciprocal Teaching and Self Efficacy on learning outcomes of AUD mathematical logic. This research is experimental research designed using treatment by level $2 \times 2$. The research method used is a variance analysis of two different cell paths. The results of this research are: (1) learning outcomes of students using Reciprocal Teaching strategy is higher than Ekspository strategy, (2) there is an interaction influence between learning strategy and self efficacy on learning outcomes of AUD mathematical logic, (3) there is an influence of self efficacy on learning outcomes of AUD mathematical logic. Keywords: Learning outcomes; Reciprocal Teaching; Self efficacy.
\end{abstract}

\section{INTRODUCTION}

Various factors that contribute to influence learning quality is learning strategy. One of strategy on learning is Reciprocal Teaching strategy. Reciprocal Teaching strategy is friend teaching activity, there is an active reciprocal, there is interaction between student and student, student and teacher on understanding reading material for creating students' knowledge (Adiwijaya, Suarsini, \& Lukiati, 2016; Maulani, Suyono, \& Noornia, 2017). Reciprocal Teaching strategy is originated from constructivist theory. Unlike Reciprocal Teaching strategy that emphasizes students, there is an Expository strategy. Expository learning strategy is a form of teacher-oriented learning approach (Teacher Centered Approach) (Hendracipta, Syachruroji, \& Hermawilda, 2017; Nur Kesumaningrum \& Syachruroji, 2016). It said, because in this strategy the teacher plays a dominant role, learning material was taught directly by the teacher. Students were not prosecuted to find the material and subject matter as if it has already been made.

From the explanation above, each strategy has strengths and weaknesses that must be investigated, so self efficacy is needed to support the success of the strategy. Self efficacy is a mental model shown by individuals to express themselves to behaviors, beliefs about how much they are capable of doing a task to obtain certain results (Kinta Marini \& Hamida, 2014; Oktaviatul Janah \& Agung, 2015; Rizkiana, 2017; Rodríguez, Regueiro, Blas, Valle, \& Cerezo, 2014). The higher self efficacy of a person, the better the possibility to work or complete the task. Conversely, the lower self efficacy of a person, the lower the performance and the completion of the tasks they carry out.

Several researches have been done to measure the influence of Reciprocal Teaching strategy on Increasing Critical Thinking Skills, Metacognitive Abilities, Oral Activities, Increasing Reading Understanding, Mathematical Communication Abilities, The Abilities of Understanding Mathematical Concepts, Increasing Independence, Writing Abilities and 
Learning Activities. (Adhani, 2014; Adiwijaya et al., 2016; Argikas \& Khuzaini, 2016; Astriani, 2017; Fitri, 2016; Komariah, Ace, \& Silviyanti, 2015; Maulani et al., 2017; Putri, 2015; T \& Lanteri, 2017). However, there is no previous research that seen based on self efficacy and see the influence of learning outcomes of AUD mathematical logic.

Based on previous research, the renewal in this research is on the Reciprocal Teaching strategy and Self Efficacy on learning outcomes of AUD mathematical logic. So, the purpose of this research is to learn about the influence of Reciprocal Teaching strategy and Self Efficacy on learning outcomes of AUD mathematical logic.

\section{THE RESEARCH METHODOS}

Experimental method was used in this research with factorial $2 \times 2$ design. As the dependant variable is learning outcomes of AUD mathematical logic, while the independent variable is learning strategies which is divided into two groups, namely Reciprocal Teaching strategy as experimental group and Expository learning strategy as control variables and self efficacy which is divided into 2 groups, namely high self efficacy and low self efficacy. The design of this research shows on Table 1:

Table 1 . Treatment design by level $2 \times 2$

\begin{tabular}{l|c|c} 
Self Efficacy (B) & \multicolumn{2}{c}{ Learning Strategy } \\
\cline { 2 - 3 } & Reciprocal Teaching (A1) & Ekspositori (A2) \\
\hline High (B1) & A1B1 & A2B1 \\
\hline Low (B2) & A1B2 & A2B2 \\
\hline
\end{tabular}

This research uses a questionnaire method to collect Data, the data analysis technique used in this research is two-way variance analysis technique (ANOVA). This technique is used to determine the significance of interactions that happen between learning strategy and self efficacy on learning outcomes of AUD mathematical logic, so that hypothesis test can be done. Prerequisite tests were needed, namely normality test and homogeneity data test. The data analysis of hypothesis test used in this research is using two-way Anova test with the following hypothesis:

$\mathrm{H}_{0} \quad$ : There is no influence between learning strategy on learning outcomes of AUD mathematical logic

$\mathrm{H}_{1} \quad$ : There is an influence between learning strategy on learning outcomes of AUD mathematical logic

The second hypothesis,

$\mathrm{H}_{0} \quad$ : There is no interaction influence between learning strategy and self efficacy on learning outcomes of AUD mathematical logic

$\mathrm{H}_{1} \quad$ : There is an interaction influence between learning strategy and self efficacy on learning outcomes of AUD mathematical logic

The third hypothesis, 


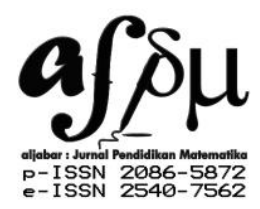

\author{
Al-Jabar: Jurnal Pendidikan Matematika \\ Vol. 9, No. 1, 2018, Hal 41 - 50
}

$\mathrm{H}_{0} \quad$ : There is no self efficacy influence on learning outcomes of AUD mathematical logic

$\mathrm{H}_{1} \quad$ : There is a self efficacy influence on learning outcomes of AUD mathematical logic Criteria of conclusions withdrawal if significant value is $<0,05 \mathrm{so}, \mathrm{H}_{0}$ is rejected.

Before using two-ways Anova test, prerequisite test was done namely normality test and homogeneity test. Normality test using Liliefors test, with test hypothesis

$\mathrm{H}_{0}$ : a normal distribution

$\mathrm{H}_{1}$ : not a normal distribution

Data distribution is said to be a normal distribution if $\mathrm{L}_{\text {Calculated }} \leq \mathrm{L}_{\text {Table }}$ so $\mathrm{H}_{0}$ is accepted or the two of them is a normal distribution, while for homogeneity test using $\mathrm{F}$ test with test hypothesis

$\mathrm{H}_{0}$ : Data distribution is homogene

$\mathrm{H}_{1}$ : Data distribution is not homogene

Data distribution is said to be homogene if the value of $\mathrm{F}_{\text {Calculated }} \leq \mathrm{F}_{\text {Table }}$ so $\mathrm{H}_{0}$ is accepted, and data distribution is homogene.

\title{
THE RESULTS OF THE RESEARCH AND THE DISCUSSION
}

Learning outcomes of AUD mathematical logic through Reciprocal Teaching and Expository learning strategy shown in Table 1

Table 1. Comparison of Learning Outcomes of AUD Mathematical Logic Through Reciprocal Teaching and Expository Learning Strategy

\begin{tabular}{llll}
$\begin{array}{llll}\text { Self } \\
\text { efficacy } \\
\text { (B) }\end{array}$ & Reciprocal Teaching (A1) & Expository (A2) & Total \\
\hline High (B1) & $\mathrm{n}=12$ & $\mathrm{n}=12$ & $\mathrm{n}=24$ \\
\cline { 2 - 4 } & $\mathrm{SD}=4,52$ & $\mathrm{SD}=3,37$ & $\mathrm{SD}=3,90$ \\
\cline { 2 - 4 } & $\bar{X}=23,49$ & $\bar{X}=2367$ & $\overline{\boldsymbol{X}}=23,58$ \\
\hline Low (B2) & $\mathrm{n}=12$ & $\mathrm{n}=12$ & $\mathrm{n}=24$ \\
\cline { 2 - 4 } & $\mathrm{SD}=3,09$ & $\mathrm{SD}=3,27$ & $\mathrm{SD}=4,14$ \\
\cline { 2 - 4 } & $\bar{X}=19,17$ & $\bar{X}=13,83$ & $\overline{\boldsymbol{X}}=16,50$ \\
\hline Total & $\mathrm{N}=24$ & $\mathrm{~N}=24$ & $\mathrm{~N}=48$ \\
\cline { 2 - 4 } & $\mathrm{SD}=4,39$ & $\mathrm{SD}=5,98$ & $\mathrm{SD}=5,35$ \\
\cline { 2 - 4 } & $\overline{\boldsymbol{X}}=21,33$ & $\overline{\boldsymbol{X}}=18,75$ & $\overline{\boldsymbol{X}}=20,04$ \\
\hline
\end{tabular}

Information :

n : Number of samples

SD : Standard Deviation

$\bar{x} \quad$ : Average Score (Mean)

Descriptive data in Table 1 shows that on Reciprocal Teaching and Expository strategies, the average score and standard deviation are obtained. Average score on Reciprocal Teaching strategy is 21.33 while on Expository strategy is 18.75. Standard deviation on Reciprocal 
Teaching strategy is 4.39 and standard deviation on Expository strategy is 5.98. Data shows that average score and standard deviation for Reciprocal Teaching strategy is bigger than Expository strategy. To test the research hypothesis, two-ways variance analysis is done with interaction (ANOVA $2 \times 2$ ). The purpose of this analysis is to see the influence of difference treatment, namely the influence of learning strategies and self efficacy and the interaction through learning outcomes of AUD mathematical logic as the dependent variables presented in Table 2.

Table 2. Variance Analysis to See The Influence of Learning Strategies and Self efficacy on Learning Outcomes of AUD Mathematical Logic

\begin{tabular}{|c|c|c|c|c|c|c|}
\hline \multirow[t]{2}{*}{ Variance Source } & \multirow[t]{2}{*}{ db } & \multirow[t]{2}{*}{$\mathbf{J k}$} & \multirow{2}{*}{$\begin{array}{l}\mathrm{RK}= \\
\mathrm{JK} / \mathrm{db}\end{array}$} & \multirow[t]{2}{*}{ Fh=RK/RKD } & \multicolumn{2}{|c|}{ Ftable } \\
\hline & & & & & 0,05 & 0,01 \\
\hline Learning Strategy (A) & 1 & 80,08 & 80,08 & $6,15^{*}$ & & \\
\hline Self Efficacy (B) & & & & & 4,06 & 7,24 \\
\hline Interaction Factor & 1 & 602,08 & 602,08 & $46,2 *$ & & \\
\hline$(\mathbf{A x B})$ & 1 & 90,75323 & 90,75 & $6,97 *$ & & \\
\hline In (D) & 44 & 573,0001 & 13,02 & - & - & - \\
\hline Total (T) & 47 & 1345,92 & - & - & - & - \\
\hline
\end{tabular}

Information :

$\mathrm{Db} \quad=$ Independent Degree of Variance Source

$\mathrm{Jk}=$ Sum of Squares of Variance Source

RK = Average Sum of Squares of Variance Source

$\mathrm{RKD}=$ Average Sum of Squares in a Group

*) Significant

$F_{h}=F_{\text {Calculated }}$ Value, $F_{t}=F_{\text {table }}$ Value

Based on variance analysis results in Table 2 above, it can be explained as follows:

1. There is a significant difference of learning strategy on learning outcomes of AUD mathematical logic in the student group who were the subjects in this research or there is a significant difference on column (A) because the value of $F_{h}=6,15>F_{t}=4,06$ at significant level of $\alpha=0,05$

2. There is a significant influence of self efficacy on learning outcomes of AUD mathematical logic in the student group who were the subjects in this research, or there is a significant influence on line (B) because the value of $F_{h}=46,2>F_{t}=4,06$ at significant level of $\alpha=$ 0,05

3. There is a significant interaction factor influence between learning strategy and self efficacy on learning outcomes of AUD mathematical logic in the student group who were 
the subjects in this research, because the value of $F_{h}=6,97>F_{t}=7,24$ at significant level of $\alpha=0,01$

From the research hypothesis test, it is proven that there is interaction between learning strategy and self efficacy on learning outcomes of AUD mathematical logic. The analysis continued with Turkey test, this analysis is conducted to examine the difference on absolute average value of two groups paired by comparing the value and critical value of HSD (honesity significant difference). Turkey test results at significant level of $(\alpha)=0,05$ are summarized in Table 3 :

Table 3. Turkey Test Results

\begin{tabular}{|c|c|c|c|c|}
\hline $\begin{array}{l}\text { Compared } \\
\text { groups }\end{array}$ & $\begin{array}{c}\text { Absolute } \\
\text { average } \\
\text { differentiator } \\
\text { value }\end{array}$ & Dk & $\begin{array}{c}\text { Critical Value } \\
\text { of HSD }\end{array}$ & Significance \\
\hline$A 1$ and $A 2$ & 3,47 & 2,46 & 2,11 & Significant \\
\hline B1 and B2 & 9,54 & $-2,46$ & 2,11 & Significant \\
\hline $\begin{array}{l}\text { A1 B1 and A2 } \\
\text { B1 }\end{array}$ & 0,16 & 4,44 & 3,95 & Not significant \\
\hline $\begin{array}{l}\text { A1 B1 and A1 } \\
\text { B2 }\end{array}$ & 4,13 & 4,44 & 3,95 & Significant \\
\hline $\begin{array}{l}\text { A1B1 } \\
\text { A2B2 }\end{array}$ & 9,29 & 4,44 & 3,95 & Significant \\
\hline $\begin{array}{l}\text { A2B1 and } \\
\text { A1B2 }\end{array}$ & 4,33 & 4,44 & 3,95 & Significant \\
\hline $\begin{array}{l}\text { A2 B1 and } \\
\text { A2B2 }\end{array}$ & 9,45 & 4,44 & 3,95 & Significant \\
\hline $\begin{array}{l}\text { A1 B2 and } \\
\text { A2B2 }\end{array}$ & 5,13 & 4,44 & 3,95 & Significant \\
\hline
\end{tabular}

The first hypothesis test shows that there is a difference on learning outcomes of AUD mathematical logic between students who were taught using Reciprocal Teaching learning strategy and students who were taught using Expository learning strategy. Learning outcomes score of the students who were taught using Reciprocal Teaching learning strategy is higher because Reciprocal Teaching learning strategy is more likely to create conducive learning condition for the students to be involved actively in the knowledge construction process. In this process of constructivism, the brain function is involved overall in the process of creating new ideas, so the self efficacy of students is more visible, trained to be responsible on learning process (Reichenberg \& Lofgren, 2014). 
Reciprocal Teaching strategy comes from constructivist theory. The implications of constructivist theory in learning are : (1) Prioritizing students' role in their own initiative of active involvement in learning activities in constructivist class, presentation of ready made knowledge is not emphasized; (2) Constructivist approaches in typical teaching apply scaffolding, with students responsible increasingly on their own learning. Reciprocal Teaching learning strategy can provide better learning outcomes because Reciprocal Teaching learning strategy was implemented by training students to compile questions, re-explain, predict and summarize. The above view is associated with learning process of AUD mathematical logic which is a general basic course to supply prospective teachers as educators so that they can understand theories that will become provisions when they practice in real life.

The second hypothesis test result shows that, "There is an interaction between learning strategies and self efficacy on learning outcomes of AUD mathematical logic". Many things are considered on learning, in addition to the selection of learning strategies, it should also pay attention to the characteristics of students including their self efficacy. The right strategy selection affects on effective learning outcomes (learning objectives are accomplished). In this research, learning outcome score of students who were taught using Reciprocal Teaching learning strategy and those who were taught using Expository learning strategy show good results. But if compared, learning outcomes of the students who were taught using Reciprocal Teaching learning strategy is higher than those who were taught using Expository learning strategy.

Reciprocal Teaching learning strategy conditions learning centered on students by exploring their abilities and potentials. Reciprocal Teaching strategy can be organized into learning activities including to those that emphasize student activity (student oriented). This activity that distinguishes from Expository learning strategy which emphasize the activities that centered on lecturers (teacher oriented). Students who used to student-centered learning process will provide receptive and passive roles, if applied using Reciprocal Teaching strategy and they will be more comfortable with Expository learning strategy. Students' learning outcomes who have a high self efficacy using Reciprocal Teaching learning strategy is higher than those with Expository learning strategy. The average learning outcome scores of the students who use Reciprocal Teaching learning strategy is 23.49 , those who use Expository learning strategy is 23.67. The average score of the students who have a low self efficacy that use Reciprocal Teaching learning strategy is 19.17 while those who use Expository learning strategy is 13.3. It identifies that learning outcomes will be well achieved if adjusted with self efficacy of students, thus learning outcomes of AUD mathematical logic will be well achieved if learning strategies that applied is in accordance with self efficacy of students.

There is a difference of learning outcomes of AUD mathematical logic between students who have a high self efficacy that get Reciprocal Teaching learning strategy and those who get Expository learning strategy. Hypothesis test result shows that there is average score difference of students who have a high self efficacy that were taught using Reciprocal Teaching learning strategy and those who were taught using Expository learning strategy. The average learning outcome score of students who have a high self efficacy that were taught using Reciprocal 
Teaching learning strategy is 23.49 while those who were taught using Expository learning strategy is 23.67. It identifies that for students who have a high self efficacy were more appropriate if Reciprocal Teaching learning strategy is given to them.

Reciprocal Teaching learning strategy is influenced by constructivism learning strategy. The Constructivism approach emphasizes on the active learning process and students as a focus in learning, the task of lecturer is to help students to construct the knowledge. In this Constructivism learning, brain function is involved overall in the process of creating new ideas, so that students' self efficacy is more encouraged, this strategy is suitable for the students who have a high self efficacy.

There is a difference of learning outcomes of AUD mathematical logic of students who have a low self efficacy that get Reciprocal Teaching learning strategy and those who get Expository learning strategy. Hypothesis test result shows that there is average score difference of students who have a low self efficacy, there is a difference of learning outcomes of AUD mathematical logic between students who were taught using Reciprocal Teaching learning strategy and those who were taught using Expository learning strategy. The average learning outcome score of students who use Reciprocal Teaching learning strategy is lower than learning outcomes of AUD mathematical logic of students who use Expository learning strategy.

The application of learning activities that use Expository learning strategy, students will be faced with certain concepts that must be memorized, so it does not prosecute students to rethink after the learning process ends, students are expected to understand it correctly by being able to reveal the matter described. Expository strategy is more influenced by behavioristic learning theory. According to behavioristic flow, learning is essentially the formation of associations between impression captured by the five senses with the tendency to act or the relationship between stimulus and response (S-R). In the implementations of Expository strategy, the role of lecturer as stimulus provider is an important factor and more dominating. The students who have low self efficacy, this Expository learning strategy made them more comfortable, so that learning outcome of students who were taught using Expository learning strategy is higher than students who were taught using Reciprocal Teaching learning strategy.

If educators know the differences in self efficacy of students, those who have a high and low self efficacy characteristics, it will be easy for them to choose and use the right learning strategies for each of these characteristics. Students who have a low self efficacy, have a number of advantages in learning, if the learning strategies used are appropriate and relevant to their learning interests and abilities. For students who have a high self efficacy, the learning outcomes will be lower if the learning strategies used are not in accordance with their characteristics. Because each strategy has certain characteristics with all its strengths and weaknesses.

Previous researchers related to the use of Reciprocal Teaching strategy towards Improving Critical Thinking Skills revealed that there was a positive influence on Reciprocal Teaching learning assisted by concept maps of students' critical thinking abilities. Students' critical thinking ability in the experimental class (the average percentage of students' critical thinking skills is $73.36 \%$ ) is higher compared to the control class (the average percentage of 
students' critical thinking abilities 53.20\%). Thus, the application of Reciprocal Teaching learning assisted by concept maps can improve students' critical thinking skills (Adiwijaya et al., 2016). The application of Reciprocal Teaching learning strategy with very positive mind map was applied. Students who have very positive perceptions of Reciprocal Teaching learning with mind map felt that through mind-assisted Reciprocal Teaching, students can develop happiness, interest, and enthusiasm toward biology so as to improve metacognitive and learning outcomes (Sukardi, Susilo, \& Zubaidah, 2015). Oral activity, Improved reading comprehension, mathematical communication skills, ability to understand mathematical concepts, increase independence, writing ability and learning activities can also be improved by using Reciprocal Teaching strategies. The advantage of Reciprocal Teaching strategy is that all centralized learning is centered on learning so that students are directly involved and will make students remember the concepts learned and can improved students' thinking skills (Adhani, 2014). Through Reciprocal Teaching learning strategy, students with positive selfconcept can develop their abilities. It is because the steps on Reciprocal Teaching can give the best results supported by students' positive view of themselves (Maulani et al., 2017)

The results of this research are reinforced by previous research related to implication of Reciprocal Teaching learning strategy that had been done by Nurefendi which shows that Reciprocal Teaching learning strategy has the potential to improve the completeness of students' learning outcomes. Ira Vahlia and Satrio Wicaksono said that Reciprocal Teaching strategy can improve mathematics learning outcomes of students (Vahlia \& Sudarman, 2015). Reski Awalia and Ridwan Idris also said that Reciprocal Teaching strategy had a positive influence in increasing mathematics learning outcomes of students (Awaliah \& Idris, 2015).

\section{CONCLUSION AND SUGGESTION}

Based on the result of analysis and data processing supported with theoretical basis and refers to the purpose of the research, so it can be concluded that there is the influence of Think Talk Write (TTW) learning model on the mathematical problem-solving abilities of the learners, there is the influence of learning habits on the mathematical problem-solving abilities of the learners, and there is no interaction between learning model and learning habits on the mathematical problem-solving abilities of the learners. It means that Think Talk Write (TTW) learning model is more effective than The Conventional learning model so Think Talk Write (TTW) learning model is more influence on the problem-solving abilities of the learners. It means that TTW learning model is more effective than The Conventional learning model. There is the difference in the problem-solving abilities of the learners who have high, moderate and low learning habits that is applied TTW learning model and those that applied The Conventional learning model. Based on the conclusion above, there are some suggestions which are: for the next research could find other learning models which more effective on mathematical problemsolving abilities of the learners and try to use the same model or other learning models by looking for other influences or by adding review of the research on affective-abilities of the learners. Hopefully, this research can be useful and be a reference for further research. 


\section{REFERENCES}

Afriyani, A. D. N., Chotim, M., \& Hidayah, I. (2014). Keefektifan Pembelajaran TTW dan SGW Berbantuan Kartu Soal Terhadap Kemampuan Pemecahan Masalah. Unnes Journal of Mathematics Education, 3(1), 48-55.

Amelia, M. (2015). Pengaruh Adversity Quotient, Iklim Kelas, dan Kebiasaan Belajar Terhadap Prestasi Belajar Ekonomi Siswa Kelas XI.IS SMA Negeri di Kabupaten Tanah Datar. Journal of Economic Education, 4(1), 149-159.

Angriani, A. D., Bernard, Nur, R., \& Nurjawahirah. (2016). Meningkatkan Kemampuan Pemecahan Masalah Melalui Pembelajaran Kooperatif Think Talk Write Pada Peserta Didik Kelas VIII MTsN Model Makassar. Jurnal Matematika dan Pembelajaran, 4(1), $11-28$.

Arifin, P. (2012). Hubungan Kebiasaan Belajar dengan Prestasi Belajar Siswa Kelas VII B SMP Negeri 13 Malang. Pd. skripsi, UM, Malang.

Atikasari, G., \& Kurniasih, A. W. (2015). Keefektifan Model Pembelajaran Kooperatif dengan Strategi TTW Berbantuan Geogebra Terhadap Kemampuan Berpikir Kreatif Matematis Siswa Kelas VII Materi Segitiga. Unnes Journal of Mathematics Education, 4(1), 85-94.

Cowan, J. (2017). The Potential of Cognitive Think Aloud Protocols for Educational Action Research. Active Learning in Higher Education, 1-14.

Dewimarni, S. (2017). Keampuan Komunikasi dan Pemahaman Konsepn ALjabar Linear Mahasiswa UNiversitas Indonesia 'YPTK' Padang. Jurnal Pendidikan Matematika , 8 (1), 53-62.

Elida, N. (2012). Meningkatkan Kemampuan Komunikasi Matematik Siswa Sekolah Menengah Pertama Melalui Pembelajaran Think Talk Write (TTW). Infinity Journal, I(2), 178-185.

Irwanto, Z. (2016). Pengaruh Teknik Problem Solving Dalam Meningkatkan Kebiasaan Belajar Siswa. Journal of Educational Science and Technology (EST), 2(3), 213-225.

Jitendra, A. K., Harwell, M. R., Dupuis, D. N., \& Karl, S. R. (2016). A Randomized Trial of The Effects of Schema Based Instruction on Proportional Problem Solving for Students With Mathematics Problem Solving Difficulties. Journal of Learning Disabilities, 50(3), $1-15$.

Juniasih, N. W., Jampel, I. N., \& Setuti, N. M. (2013). Pengaruh Model Pembelajaran Think Talk Write (TTW) Berbantuan Media Konkret Terhadap Hasil Belajar IPA Siswa Kelas IV SD. Mimbar PGSD Undiksha, l(1).

Misel, E. S. (2016). Penerapan Pendekatan Matematika Realistik Untuk Meningkatkan Kemampuan Representasi Matematis Siswa. Metoda Didaktik, 10 (2), 27-36.

Morin, L. L., Watson, S. M. R., Hester, P., \& Raver, S. (2017). The Use of a Bar Model Drawing to Teach Word Problem Solving to Students With Mathematics Difficulties. Learning Disability Quarterly, 40(2), 1-14. 
Nugroho, A. A., Putra, R. W. Y., Putra, F. G., \& Syazali, M. (2017). Pengembangan Blog Sebagai Media Pembelajaran Matematika. Al-Jabar: Jurnal Pendidikan Matematika, 8(2), 197-204.

Nurdeni, \& Liberna, H. (2012). Pengaruh Kebiasaan Belajar Dan Kreativitas Belajar Siswa Terhadap Hasil Belajar Matematika (Survey Pada SMA Di Kecamatan Ciledug Tangerang. Jurnal Fourier, 1(2), 71-76.

Siagian, R. E. F. (2013). Pengaruh minat dan kebiasaan belajar siswa terhadap prestasi belajar matematika. Jurnal Formatif, 2(2), 122-131.

Spooner, F., Saunders, A., Root, J., \& Brosh, C. (2017). Promoting Access to Common Core Mathematics for Students with Severe Disabilities Through Mathematical Problem Solving. Research and Practice for Persons with Severe Disabilities, 42(3), 171-186.

Sugiarti, N. L. P. Y., Putra, I. K. A., \& Abadi, I. B. G. S. (2014). Pengaruh Model Pembelajaran TTW (Think Talk Write) Berbantuan Media Gambar Berseri Terhadap Keterampilan Menulis Bahasa Indonesia Siswa Kelas V SD Gugus 1 Kecamatan Kediri, Tabanan Tahun Ajaran 2013/2014. Mimbar PGSD Undiksha, 2(1).

Wahyuni, R., \& Efuansyah. (2018). Model Pembelajaran Missouri Mathematics Project (MMP) Menggunakan Strategi Think Talk Write (TTW) Terhadap Kemampuan Berpikir Kritis dan Kemampuan Pemecahan Masalah. Jurnal Nasional Pendidikan Matematika, 2(1), 24-36. 